\title{
PEMBIAYAAN BERMASALAH DI BANK SYARIAH
}

\author{
Suhaimi \\ STIT Manna Bengkulu Selatan \\ Email: suhaimi@gmail.com \\ Asnaini \\ FEBI IAIN Bengkulu \\ Email : asnaasnaini@gmail.com
}

\begin{abstract}
Financing is a process from the analysis of the feasibility of financing to the realization. Realization of financing is not the last stage of the financing process. After the financing realization, sharia banks need to conduct monitoring and supervision of financing, because in term of financing is not impossible to occur problematic financing due to several reasons. Islamic banks should be able to analyze the causes of problem financing so that it can make an effort to reinvent the quality of the financing.

Keywords: Troubled Financing, Criteria, Merchandising, and Settlement
\end{abstract}

Abstrak: Pembiayaan adalah suatu proses mulai dari analisis kelayakan pembiayaan sampai kepada realisasinya. Realisasi pembiayaan bukanlah tahap terakhir dari proses pembiayaan. Setelah realisasi pembiayaan, bank syariah perlu melakukan pemantauan dan pengawasan pembiayaan, karena dalam jangka waktu pembiayaan tidak mustahil terjadi pembiayaan bermasalah dikarenakan beberapa alasan. Bank syariah harus mampu menganalisis penyebab pembiayaan bermasalah sehingga dapat melakukan upaya untuk melancarkan kembali kualitas pembiayaan tersebut.

Kata kunci: Pembiayaan Bermasalah, Kriteria, Penyelematan, dan Penyelesaian

\section{A. PENDAHULUAN}

Pembiayaan atau financing adalah pendanaan yang diberikan oleh suatu pihak kepada pihak lain untuk mendukung investasi yang telah direncanakan, baik dilakukan sendiri maupun lembaga. Jadi, pembiayaan adalah pendanaan yang dikeluarkan untuk mendukung investasi yang telah direncanakan. ${ }^{1}$

Dalam pelaksanaannya, sebagian besar asset dari bank syariah adalah pembiayaan. Karena itu pembiayaan harus dijaga kualitasnya. Dalam Undangundang Perbankan Syariah Pasal 2 disebutkan bahwa "perbankan syariah

${ }^{1}$ Muhamad, Manajemen Pembiayaan Bank Syariah (Yogyakarta: UPP AMP YKPN, 2005), h. 17. dalam melakukan kegiatan usahanya berasaskan prinsip syariah, demokrasi ekonomi, dan prinsip kehatihatian."2 Penerapan prinsip kehatihatian dijabarkan dalam bentuk rambu-rambu kesehatan bank. 3 Undang-Undang Perbankan Syariah, pasal 23 (1) mengatur bahwa "Bank syariah dan/atau UUS harus mempunyai keyakinan atas kemauan dan kemampuan calon nasabah

\footnotetext{
${ }^{2}$ Prinsip kehatihatian adalah pengendalian risiko melalui penerapan peraturan perundangundangan dan ketentuan yang berlaku secara konsisten.Yahman dan Trisadini Prasastinah Usanti dan Prasastinah Usanti, Bunga Rampai Hukum Aktual Dalam Perspektif Hukum Bisnis Kontraktual Berimplikasi Pidana dan Perdata (Surabaya: Mitra Mandiri, 2011), h. 136.

${ }^{3}$ Pada penjelasan Pasal 2 Undang-Undang Perbankan Syariah yang dimaksud dengan prinsip kehatihatian adalah pedoman pengelolaan Bank yang wajib dianut guna mewujudkan perbankan yang sehat, kuat dan efisien sesuai dengan ketentuan peraturan perundang-undangan.
} 
penerima fasilitas untuk melunasi seluruh kewajiban pada waktunya, sebelum Bank Syariah dan/ atau UUS menyalurkan dana kepada nasabah penerima fasilitas". Untuk mendapatkan keyakinan maka bank syariah wajib melakukan penilaian yang seksama terhadap kemampuan, modal, agunan, dan prospek usaha dari calon nasabah penerima fasilitas (character, capacity, capital, collateral, condition)." Pada Pasal 36 juga diatur bahwa "Dalam memberikan pembiayaan dan melakukan kegiatan usaha lainnya, Bank Syariah dan UUS wajib menempuh cara-cara yang tidak merugikan Bank Syariah dan UUS dan kepentingan nasabah yang mempercayakan dananya". Aturan ini berimplikasi pada bank syariah dalam memberikan pembiayaan wajib mempunyai keyakinan atas kemauan dan kemampuan dari nasabah penerima fasilitas.

Prinsip kehatihatian bertujuan agar bank-bank selalu dalam keadaan sehat, selalu dalam keadaan likuid, solvent dan menguntungkan (profitable). Dengan diberlakukannya prinsip kehatihatian ini diharapkan kadar kepercayaan masyarakat terhadap perbakan selalu tinggi sehingga masyarakat bersedia dan tidak ragu-ragu menyimpan dananya di bank. $^{4}$ Dengan kata lain dalam pembiayaan bank syariah sebisa mungkin

\footnotetext{
${ }^{4}$ Sutan Remy Sjadeini, Kapita Selecta Hukum Perbankan Jilid I, t.tp: t.th, h. 53
}

menhindari terjadinya pembiayaan bermasalah/ kegagalan dalam pembiayaan.

Jika hal itu terjadi, maka sumber pelunasan pembiayaan adalah dari usaha nasabah yang menghasilkan pendapatan (revenue) yang disebut first way out dan second way out berupa agunan (collateral). Dalam pembiayaan bermasalah, bank berhak menjual benda agunan yang dibebani dengan hak jaminan dan mengambil hasil penjualan atas benda tersebut sebagai sumber pelunasan pembiayaan. Jaminan merupakan hal penting untuk diperhitungkan bagi bank karena jaminan merupakan sumber pelunasan bilamana nasabah mengalami kegagalan pembiayaan Syariah.

\section{B. PEMBIAYAAN BERMASALAH}

Secara umum pengertian pembiayaan bermasalah adalah pembiayaan yang diakibatkan oleh nasabah yang tdak menempati jadwal pembayaran angsuran dan tidak memenuhi persyaratan yang tertuang dalam akad. Mahmoeddin mengemukakan pengertian pembiayaan bermasalah lebih spesifik lagi, yaitu pembiayaan yang kurang lancar, dimana nasabahnya tidak memenuhi persyaratan yang telah dituangkan dalam akad, pembiayaan yang tidak menempati jadwal angsuran, sehingga terjadinya penunggakan. Pembiayaan bermasalah 
adalah pembiayaan yang tidak menempati janji pembayaran, sehingga memerlukan tindakan hukum untuk menagihnya, kemudian Mahmoedin juga menyimpulkan bahwa pembiayaan bermasalah adalah pembiayaan yang berpotensi untuk merugikan bank sehingga berpengaruh terhadap kesehatan bank itu sendiri. ${ }^{5}$

Ada 5 (lima) jenis kualitas pembiayaan pada perbankan yaitu: lancar, dalam perhatian khusus, kurang lancar, diragukan dan macet. Pembiayaan bermasalah adalah kualitas pembiayaan yang mulai masuk golongan dalam perhatian khusus sampai golongan Macet. Bank syariah wajib untuk menggolongkan kualitas aktiva produktif sesuai dengan kriterianya dan dinilai secara bulanan. Jika tidak dilakukan maka akan dikenakan sanksi administratif. $^{6}$

Kualitas pembiayaan pada hakikatnya didasarkan atas risiko terhadap kepatuhan nasabah dalam memenuhi kewajibannya. Hal ini sebagaimana mengacu pada ketentuan PBI No.9/9/PBI/2007 dan PBI No.10/24/PBI/2008 tentang penetapan kualitas pembayaran, yang mana kualitas

\footnotetext{
${ }^{5}$ Azharsyah Ibrahim dan Arinal Rahmati, "Analisis Solutif Penyelesaian Pembiayaan Bermasalah di Bank Syariah: Kajian Pada Produk Murabahah di Bank Muamalat Indonesia Banda Aceh" Iqtishadia, Vol. 10, No.1, 2017, h. 76

${ }^{6}$ Lihat: Pasal 56 Undang-Undang Perbankan Syariah.
}

pembayaran dinilai berdasarkan aspek prospek usaha, kinerja nasabah dan kemampuan membayar. Penetapan kualitas tersebut dilakukan dengan mempertimbangkan materialitas dan signifikansi dari faktor penilaian komponen serta relevansinya dari faktor penilaian terhadap karakteristik penetapan pembayaran angsuran nasabah tersebut. Pembiayaan bermasalah cenderung lebih lebih berisiko terjadi pada produk-produk dengan persentase alokasi dana yang tinggi seperti pembiayaan murabahah.

Secara spesifik, risiko yang terjadi pada pembiayaan murabahah di antaranya terkait dengan barang yang timbul karena kehilangan atau kerusakan dari waktu pembelian sampai waktu pengiriman. Kemudian risiko yang terkait dengan penolakan atau pembatalan pembelian barang oleh nasabah. Selanjutnya riksiko yang terkait dengan pembayarannya yang terjadi apabila nasabah tidak membayar penuh atau sebagian dari uang muka, sebagaimana yang telah direncanakan dalam kontrak pembiayaan.

Selanjutnya, menurut Ismail risiko pembiayaan yang terjadi dari peminjam adalah tertunda atau ketidakmampuan peminjam memenuhi ketentuanketentuan dalam akad sehingga dana yang disalurkann tidak sepenuhnya 
kembali. Kondisi ini menimbulkan permasalahan berantai dalam pelaksanaan operasional bank, mulai dari tidak terealisasinya target penyaluran dana sampai dengan pendapatan laba yang lebih kecil. Akibatnya bank mengalami defisit dan berefek kepada nasabah yang menginvestasikan modalnya. $^{7}$

Ada beberapa faktor penyebab pembiayaan bermasalah $:^{8}$

1. Faktor Intern (Berasal dari pihak bank)

a. Kurang baiknya pemahaman atas bisnis nasabah;

b. Kurang dilakukan evaluasi keuangan nasabah;

c. Kesalahan setting fasilitas pembiayaan (berpeluang melakukan sidestreaming) ${ }^{9}$

d. Perhitungan modal kerja tidak didasarkan kepada bisnis usaha nasabah;

e. Proyeksi penjualan terlalu optimis;

f. Proyeksi penjualan tidak memperhitungkan kebiasaan bisnis dan kurang memperhitungkan aspek kompetitor;

g. Aspek jaminan tidak diperhitungkan aspek marketabel;

h. Lemahnya supervisi dan monitoring;

${ }^{7}$ Azharsyah Ibrahim dan Arinal Rahmati, "Analisis Solutif...., h. 77-78

${ }^{8}$ Trisadini Prasastinah Usanti dan Prasastinah Usanti, Bunga Rampai Hukum..., h.33-35. ${ }^{9}$ Dana digunakan oleh nasabah tidak sesuai dengan peruntukkan pembiayaan yang telah disepakati dalam perjanjian. i. Terjadinya erosi mental: kondisi ini dipengaruhi timbal balik antara nasabah dengan pejabat bank sehingga mengakibatkan proses pemberian pembiayaan tidak didasarkan pada praktek perbankan yang sehat.

\section{Faktor Ekstern}

a. Karakter nasabah tidak amanah (tidak jujur dalam memberikan informasi dan laporan tentang kegiatannya);

b. Melakukan sidestreaming penggunaan dana;

c. Kemampuan pengelolaan nasabah tidak memadai sehingga kalah dalam persaingan usaha;

d. Usaha yang dijalankan relatif baru;

e. Bidang usaha nasabah telah jenuh;

f. Tidak mampu menanggulangi masalah/ kurang menguasai bisnis;

g. Meninggalnya key person;

h. Perselisihan sesama direksi;

i. Terjadi bencana alam;

j. Adanya kebijakan pemerintah: peraturan suatu produk atau sektor ekonomi atau industri dapat berdampak positif maupun negatif bagi perusahaan yang berkaitan dengan industri tersebut.

Sedangkan faktor fiktif merupakan faktor- faktor yang diakibatkan oleh adanya manipulasi terhadap permohonan pembiayaan dan jaminan, baik yang dilakukan oleh nasabah maupun bank. 
Bentuk-bentuk manipulasi yang pernah terjadi adalah sebagai berikut: ${ }^{10}$

1. Fiktif Pembiayaan

Fiktif pembiayaan adalah penipuan yang sengaja dilakukan oleh nasabah dalam mengambil pembiayaan. Hal sepertinya terjadi ketika nasabah mengajukan permohonan pembiayaan, tetapi peruntukannya bagi orang lain. Secara prinsip, pemanfaatan dana tersebut harus dilakukan oleh nasabah yang mengajukan pembiayaan, tetapi fakta di lapangan tidak demikian. Di sinilah awal mulanya terjadi pembiayaan fiktif sehingga memunculkan masalah penagihan ketika terjadi penunggakan pembayaran.

2. Faktor Fiktif Terhadap Jaminan

Yaitu penipuan terhadap jaminan yang disyaratkan dalam akad yang dilakukan baik oleh nasabah maupun bank.

a. Fiktif jaminan terjadi ketika nasabah mengajukan pembiayaan dengan melampirkan jaminan atau sertifikat milik orang lain yang dirubah menjadi atas nama nasabah tersebut. Berdasarkan fakta di lapangan, sertifikat yang dilampirkan biasanya milik salah satu anggota keluarganya yang

${ }^{10}$ Azharsyah Ibrahim dan Arinal Rahmati, “Analisis Solutif...., h. 86-87 dirubah namanya untuk keperluan pengajuan pembiayaan saja tanpa proses jual beli yang sebenarnya. Ketika terjadi pembiayaan bermasalah, pihak bank kesulitan untuk mengeksekusi agunan tersebut.

b. Fiktif jaminan yang bisa disebabkan oleh faktor internal bank. Kasus ini dipicu ketika ada nasabah yang tidak layak untuk mendapatkan pembiayaan menghubungi oknum tertentu dalam internal bank. Mereka membuat deal agar pengajuan tersebut dapat diterima dan oknum tersebut akan mendapatkan besaran tertentu dari pembiayaan tersebut. Hal ini terjadi karena tidak semua karyawan yang bekerja pada bank tersebut mempunyai dedikasi dan loyalitas yang tinggi terhadap perusahaannya. Selain itu, tidak semua karyawan mengetaui dan sepenuhnya memahami serta menguasai kode etik dan SOP perbankan syariah.

Pembiayaan bermasalah biasanya muncul secara bertahap dengan didahului oleh beberapa gejala (reg flags). Menurut Mahmoedin gejala-gejala tersebut berupa: 
1. Perilaku Rekening (Account Attitudes)

Perilaku rekening nasabah dapat memberikan indikasi tentang gejala awal munculnya masalah, misalnya saldo rekening sering mengalami overdraf, saldo giro rata-rata menurun, terjadi penurunan saldo secara drastis, pembayaran pokok angsuran tersendat-sendat, jadwal pencairan dana pembiayaan tidak sesuai dengan akad pembiayaan, sering mengajukan permintaan penundaan atau perpanjangan pembayaran, penyimpangan penggunaan pembiayaan, mengajukan penambahan pembiayaan dan mengajukan penjadwalan ulang pembiayaan.

2. Perilaku Laporan Keuangan (Fiancial Statement Attitudes)

Berdasarkan perilaku laporan keuangan, gejala pembiayaan bermasalah dapat berupa penurunan likuiditas, penurunan perputaran modal pembiayaan, peningkatan piutang, penurunan perputaran modal pembiayaan, peningkatan piutang, penurunan perputaran persediaan, penurunan rasio aktiva lancar terhadap aktiva total, penurunan aktiva tetap, penjualan meningkat namun laba menurun, debt equity ratio meningkat, utang jangka panjang meningkat tajam, muncul hutang dari bank lain, rasio keuntungan terhadap aset penurunan, laporan keuangan sering terlambat, laporan keuangan tidak diaudit, persentase laba terhadap aktiva menurun, laporan keuangan direkayasa, harga penjualan terlalu rendah dan berda di bawah titik impas.

3. Perilaku Kegiatan Bsnis (Business Activities Attitudes)

Dalam kategori ini, gejala pembiayaan bermasalah ditandai bermasalah ditandai dengan penurunan supply barang, hubungan dengan pelanggan memburuk, harga jual terlampau rendah, kehilangan hak sebagai distributor, kehilangan pelanggan utama, mulai terlibat spekulasi bisnis, hubungan dengan bank semakin renggang, enggan dikunjungi, keterlibatan dengan usaha lain, ada informasi negatif dari pihak lain, ada klaim dari pihak ketiga, ada pemogokan buruh, nilai agunan menurun, nasabah alih usaha pokok, mencari pinjaman baru.

4. Perilaku Nasabah (Customer Attitudes) Gejala pembiayaan bermasalah yang muncul dalam kategori diantaranya: kesehatan nasabah memburuk, terjadi sengketa rumah tangga, telepon dari bank sering tidak dijawab, nasabah mempunyai kegiatan tertentu dan lainlain. $^{11}$

\section{PENYELAMATAN PEMBIAYAAN BERMASALAH}

${ }^{11}$ Azharsyah Ibrahim dan Arinal Rahmati, "Analisis Solutif..., h. 78-79 
Idealnya, pembiayaan yang telah diberikan oleh bank syariah bisa berjalan dengan lancar. Nasabah mematuhi apa yang telah disepakati dalam akad. Akan tetapi, dalam pelaksanaannya, bisa nasabah mengalami kesulitan dalam pembayaran yang berakibat pada tidak atau kurang lancarnya pembiayaan, yang bisa berujung pada kerugian bagi pihak bank syariah dan tidak menutup kemungkinan kerugian pada pihak nasabah. Jika terjadi pembiayaan bermasalah, maka bank syariah akan melakukan upaya untuk menangani pembiayaan bermasalah tersebut.

Pengelolaan Bank yang optimal dalam aktivitas Pembiayaan dapat meminimalisasi potensi kerugian yang akan terjadi. Pengelolaan tersebut antara lain dilakukan melalui Restrukturisasi Pembiayaan. Pelaksanaan Restrukturisasi Pembiayaan pada Bank, harus tetap memenuhi prinsip syariah disamping mengacu kepada prinsip kehatihatian yang bersifat universal yang berlaku pada industri perbankan. Selain itu, aspek kebutuhan dan kesesuaian dengan perkembangan industri perbankan syariah menjadi pertimbangan dalam penyempurnaan ketentuan mengenai Restrukturisasi Pembiayaan di Bank Syariah dan Unit Usaha Syariah. ${ }^{12}$

\footnotetext{
${ }^{12}$ Penjelasan Peraturan Bank Indonesia Nomor 13/9/PBI/2011 Tentang perubahan atas Peraturan Bank Indonesia Nomor 10/PBI/2008
}

Setiap terjadi pembiayaan bermasalah maka bank syariah akan berupaya untuk menyelamatkan pembiayaan. Berdasarkan Peraturan Bank Indonesia Nomor 13/9/PBI/2011 Tentang perubahan atas Peraturan Bank Indonesia Nomor 10/PBI/2008 Tentang Restrukturisasi Pembiayaan bagi Bank Syariah dan Unit Usaha Syariah. Restrukturisasi pembiayaan adalah upaya yang dilakukan bank untuk membantu nasabah agar dapat menyelesaikan kewajibannya, antara lain melalui:

1. Penjadwalan kembali (rescheduling), yaitu perubahan jadwal pembayaran kewajiban nasabah atau jangka waktunya; ${ }^{13}$

2. Persyaratan kembali (reconditioning), yaitu perubahan sebagian atau seluruh persyaratan Pembiayaan tanpa menambah sisa pokok kewajiban nasabah yang harus dibayarkan kepada Bank, antara lain meliputi:

a. perubahan jadwal pembayaran;

b. perubahan jumlah angsuran;

c. perubahan jangka waktu;

d. Perubahan nisbah dalam pembiayaan mudharabah atau musyarakah;
Tentang Restrukturisasi Pembiayaan Bagi Bank Syariah dan Unit Usaha Syariah

${ }^{13}$ Berdasarkan SEBI No.13/18/DPbS tanggal 
e. Perubahan proyeksi bagi hasil dalam pembiayaan mudharabah atau musyarakah;

f. Pemberian potongan.

3. Penataan kembali (restructuring), yaitu perubahan persyaratan Pembiayaan yang antara lain meliputi:

a. Penambahan dana fasilitas pembiayaan bank;

b. Konversi akad pembiayaan;

c. Konversi pembiayaan menjadi surat berharga syariah berjangka waktu menengah; dan/atau;

d. Konversi pembiayaan menjadi penyertaan modal sementara pada perusahaan nasabah, yang dapat disertai dengan rescheduling atau reconditioning.

Berdasarkan SEBI No.13/18/DPbS tanggal 30 Mei 2011 Tentang Perubahan atas SEBI Nomor 10/34/DPbS tanggal 22 Oktober 2008 Tentang Restrukturisasi Pembiayaan Bagi Bank Syariah dan Unit Usaha Syariah bahwa Bank Uumum Syariah (BUS) atau Unit Usaha Syariah (UUS) akan menghentikan akad Pembiayaan dalam bentuk piutang murabahah atau piutang istishna' dengan memperhitungkan nilai wajar obyek murabahah atau istishna'. Dalam hal terdapat perbedaan antara jumlah kewajiban nasabah dengan nilai wajar obyek murabahah atau istishna', maka diakui sebagai berikut: ${ }^{14}$

1. apabila nilai wajar lebih kecil daripada jumlah kewajiban nasabah, maka sisa kewajiban nasabah tersebut tetap menjadi hak BUS atau UUS, yang penyelesaiannya disepakati antara BUS atau UUS dan nasabah;

2. apabila nilai wajar lebih besar daripada jumlah kewajiban nasabah, maka selisih nilai tersebut diakui sebagai uang muka ijarah muntahiya bittamlik atau menambah porsi modal nasabah untuk musyarakah atau mengurangi modal mudharabah dari BUS atau UUS.

Bank hanya dapat melakukan restrukturisasi pembiayaan terhadap nasabah yang memenuhi kriteria sebagai berikut :

a. Nasabah mengalami penurunan kemampuan pembayaran; dan

b. Nasabah memiliki prospek usaha yang baik dan mampu memenuhi kewajiban setelah restrukturisasi.

Sedangkan restrukturisasi untuk Pembiayaan konsumtif hanya dapat dilakukan untuk nasabah yang memenuhi kriteria sebagai berikut:

a. nasabah mengalami penurunan kemampuan pembayaran; dan

\footnotetext{
${ }^{14}$ SEBI No. 13/18/DPbS tanggal $30 \mathrm{Mei}$ 2011 Tentang Perubahan atas SEBI Nomor 10/34/DPbS tanggal 22 Oktober 2008 Tentang Restrukturisasi Pembiayaan Bagi Bank Syariah dan Unit Usaha Syariah
} 
b. terdapat sumber pembayaran angsuran yang jelas dari nasabah dan mampu memenuhi kewajiban setelah restrukturisasi.

Berdasarkan uraian di atas, jelas bahwa restrukturisasi pembiayaan wajib didukung dengan analisis dan bukti-bukti yang memadai. Hal ini akan dapat terlaksana jika semua bukti didokumentasikan dengan baik. Penyelamatan pembiayaan bermasalah dengan restrukturisasi dilakukan apabila nasabah masih mempunyai i'tikad baik dalam upaya penyelamatan pembiayaan bermasalah tersebut. Jika tidak, maka bank syariah akan melakukan upaya penyelesaian pembiayaan bermasalah.

Dalam analisis syariah, dasar yang dapat mendukung upaya restrukturisasi pembiayaan bermasalah adalah:

Pertama, al-Quran surat alBaqarah ayat 276:

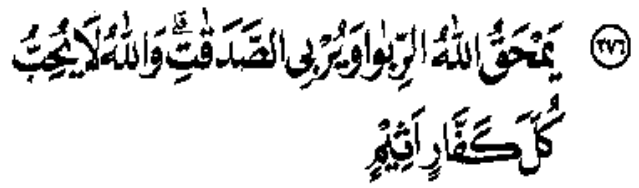

"Allah memusnahkan riba dan menyuburkan sedekah dan Allah tidak menyukai setiap orang yang tetap dalam kekafiran dan selalu berbuat dosa".

"Memusnahkan riba" yaitu memusnahkan harta itu atau meniadakan berkahnya. "Menyuburkan sedekah" yaitu memperkembangkan harta yang telah dikeluarkan sedekahnya atau melipatgandakan berkahnya.
Kedua, al-Quran surat al-Baqarah ayat 280 :

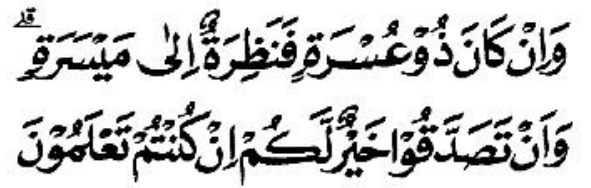

"Dan jika (orang berutang itu) dalam kesulitan, maka berilah tenggang waktu sampai dia memperoleh kelapangan. Dan jika kamu menyedekahkan, itu le-bih baik bagimu, jika kamu mengetahui"

Ketiga, al-Quran surat al-Baqarah ayat 286 :

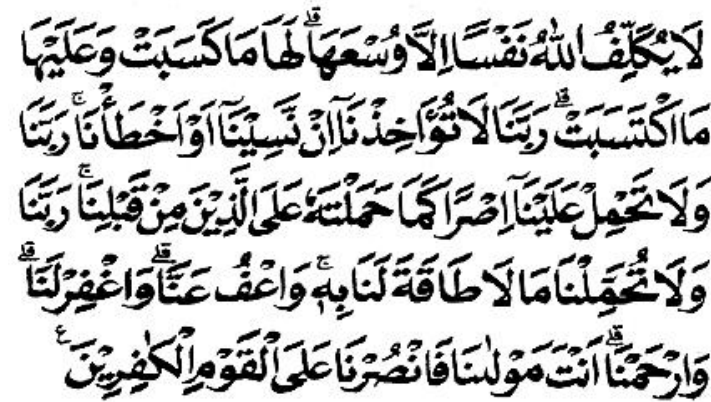

"Allah tidak membebani seseorang melainkan sesuai dengan kesanggupannya. Dia mendapat (pahala) dari (kebajikan) yang dikerjakannya dan dia mendapat (siksa) dari (kejahatan) yang diperbuatnya. (Mereka berdoa), "Ya Tuhan kami, janganlah Engkau hukum kami jika kami lupa atau kami melakukan kesalahan. Ya Tuhan kami, janganlah Engkau bebani kami dengan beban yang berat sebagaimana Engkau bebankan kepada orang-orang sebelum kami. Ya Tuhan kami, janganlah Engkau pikulkan kepada kami apa yang tidak sanggup kami memikulnya. Maafkanlah kami, ampunilah kami, dan rahmatilah kami. Engkaulah pelindung kami, maka tolonglah kami menghadapi orang-orang kafir."

Berdasarkan ayat di atas, Syariah Islam menekankan pentingnya sedekah 
dan perlunya toleransi terhadap nasabah yang sedang mengalami kesulitan (dalam arti sebenar-benarnya) membayar kembali kewajibannya.

Rasulullah SAW yang diriwayatkan dari Muslim bersabda:

"Orang yang melepaskan seorang muslim dari kesulitannya di dunia, Allah akan lepaskan kesulitannya di hari kiamat dan Allah senantiasa menolong hamba-Nya selama ia (suka) menolong saudaranya."

\section{PENYELESAIAN PEMBIAYAAN BERMASALAH}

Pada tahapan penyelesaian pembiayaan bermasalah, kebijakan yang dilakukan terhadap pembiayaan bermasalah adalah sebagai berikut:

\section{Penyelesaian Melalui On The Spot (OTS)}

Kebijakan ini dilakukan dengan cara turun ke lapangan untuk melihat langsung jaminan dan prospek usaha nasabah. Tujuannya adalah untuk melihat jika jaminan tersebut bisa terback-up dengan sisa pembayaran angsuran. Selanjutnya adalah melihat prospek usaha dan keadaan ekonomi nasabah untuk menentukan apakah bisa menutupi sisa angsurannya. ${ }^{15}$

\section{Penyelesaian Melalui Eksekusi Jaminan}

Penyelesaian melalui jaminan dilakukan oleh bank syariah bilamana

\footnotetext{
${ }^{15}$ Azharsyah Ibrahim dan Arinal Rahmati, “Analisis Solutif..., h. 87-88
}

berdasarkan evaluasi ulang pembiayaan, prospek usaha nasabah tidak ada, dan atau nasabah tidak kooperatif untuk menyelesaikan pembiayaan atau upaya penyelamatan dengan upaya restrukturisasi tidak membawa hasil melancarkan kembali pembiayaan tersebut.

Jika hal tersebut terjadi, maka upaya selanjutnya adalah penyelesaian pembiayaan bermasalah dengan cara eksekusi jaminan. Eksekusi jaminan disesuaikan dengan lembaga jaminan yang membebani benda jaminan tersebut, rahn (gadai syariah), jaminan hipotik, jaminan hak tanggungan, dan jaminan fidusia. Pada jaminan hipotik, eksekusi agunan diatur pada Pasal 1178 BW. Pada jaminan hak tanggungan diatur berdasarkan Pasal 20 Undang-Undang No. 4 Tahun 1996, bilamana debitur cidera janji ada 3 alternatif yang dapat dilakukan oleh bank yaitu:

a. Berdasarkan hak pemegang, hak tanggungan pertama untuk menjual obyek hak tanggungan sebagaimana dimaksud dalam Pasal 6 , atau

b. Berdasarkan titel eksekutorial yang terdapat dalam sertifikat hak tanggungan sebagaimana pada Pasal 14 (2).

obyek hak tanggungan dijual melalui pelelangan umum menurut 
tatacara yang ditentukan dalam peraturan perundang-undangan untuk pelunasan piutang pemegang hak tanggungan dengan hak mendahulukan para kreditur-kreditur. Selain itu atas kesepakatan penjualan obyek jaminan dapat dilaksanakan di bawah tangan, jika dengan cara demikian akan dapat diperoleh harga tertinggi.

Pada jaminan fidusia berdasarkan Pasal 29 Undang-Undang Nomor 42 Tahun 1999 apabila debitur wanprestasi maka obyek jaminan dapat dieksekusi dengan cara :

a. pelaksanaan titel eksekutorial;

b. penjualan benda yang menjadi obyek jaminan fidusia atas kekuasaan penerima fidusia sendiri melalui pelelangan umum;

c. penjualan di bawah tangan berdasarkan kesepakatan.

Dalam Undang-undang Perbankan Syariah Pasal 40, bank syariah dan UUS dapat membeli sebagian atau seluruh agunan, baik melalui maupun di luar pelelangan, berdasarkan penyerahan secara sukarela oleh pemilik agunan atau berdasarkan pemberian kuasa untuk menjual dari pemilik agunan, dengan ketentuan: agunan yang dibeli tersebut wajib dicairkan selambat-lambatnya dalam jangka waktu 1 (satu) tahun.
Dalam hal harga pembelian agunan melebihi jumlah kewajiban nasabah kepada bank syariah dan UUS, selisih kelebihan jumlah tersebut harus dikembalikan kepada nasabah setelah dikurangi dengan biaya lelang dan biaya lain yang terkait langsung dengan proses pembelian agunan.

Berkaitan dengan hal ini, yang menjadi landasan dalam ketentuan syariah Islam dapat difahami dalam surat al-Baqarah ayat 283:

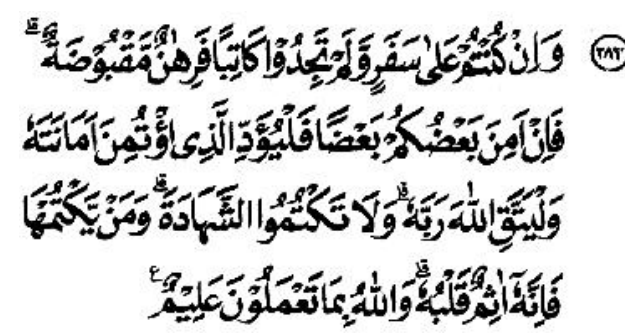

" Dan jika kamu dalam perjalanan sedang kamu tidak mendapatkan seorang penulis, maka hendaklah ada barang jaminan yang dipegang. Tetapi, jika sebagian kamu mempercayai sebagian yang lain, hendaklah yang dipercayai itu menunaikan amanatnya (utangnya) dan hendaklah dia bertakwa kepada Allah, Tuhannya. Dan janganlah kamu menyembunyikan kesaksian, karena barangsiapa menyembunyikannya, sungguh, hatinya kotor (berdosa). Allah Maha Mengetahui apa yang kamu kerjakan."

Diceritakan pula dari Hadis dari Aisyah bahwasanya Nabi Muhammad SAW pernah membeli bahan makanan dari seorang Yahudi dengan hutang dan beliau memberikan baju besinya sebagai jaminan (HR. Bukhari, Muslim dan al-Nasa'i). 
Hadis lain, dari Abu Hurairah

r.a. bahwa Rasulullah SAW bersabda:

"Siapapun yang bangkrut (muflis), lalu krediturnya mendapatkan barangnya sendiri pada si muflis, maka kreditur itu lebih berhak untuk menarik kembali barangnya daripada orang lain. (HR.Bukhari, Muslim, at-Tirmidzi, al-Nasa'i dan Ibnu Majah).

\section{Penyelesaian Melalui Badan} Arbitrase Syariah Nasional (Non Litigasi)

Berdasarkan klausula dalam perjanjian pembiayaan, jika salah satu pihak tidak menunaikan kewajibannya atau terjadi perselisihan diantara kedua belah pihak dan tidak tercapai kesepakatan melalui musyawarah, maka penyelesainya bisa dilakukan melalui Badan Arbitrase Syariah Nasional (BASYARNAS).

BASYARNAS berwenang:

1)Menyelesaikan secara adil dan cepat sengketa muamalah (perdata) yang timbul dalam bidang perdagangan, keuangan, industri, jasa dan lain-lain yang menurut hukum dan peraturan perundang-undangan dikuasai sepenuhnya oleh pihak yang bersengketa, dan para pihak sepakat secara tertulis untuk menyerahkan penyelesaiannya kepada BASYARNAS sesuai dengan prosedur BASYARNAS; 2) Memberikan pendapat yang mengikat atas permintaan para pihak tanpa adanya suatu sengketa mengenai persoalan berkenan dengan suatu perjanjian. ${ }^{16}$

Kesepakatan untuk menyerahkan penyelesaian sengketa kepada BASYARNAS, dilakukan oleh pihak:

a. Dengan mencantumkan klausula arbitase dalam suatu naskah perjanjian; atau

b. Dengan perjanjian arbitrase tersendiri yang dibuat dan disetujui oleh para pihak, baik sebelum maupun sesudah timbul sengketa.

Keputusan arbitrase merupakan keputusan terkahir dan mengikat (final and biding).

Berkaitan dengan hal ini, yang menjadi landasan dalam ketentuan syariah Islam dapat difahami dalam surat al-Hujarat ayat 9:

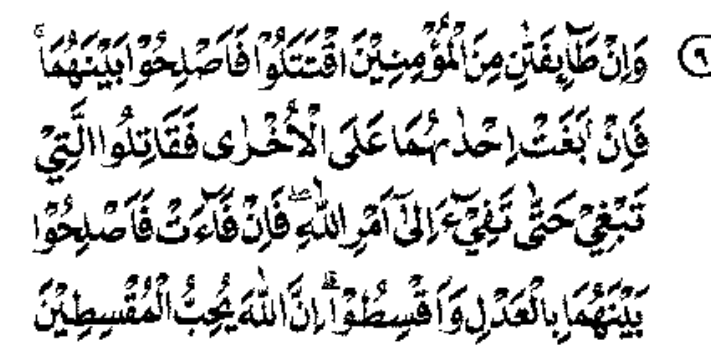

"Dan jika ada dua golongan orang yang beriman berperang (bersengketa), maka damaikan keduanya. Jika salah satu dari keduanya berbuat aniaya terhadap yang lain, maka perangilah golongan yang berbuat aniaya itu sampai mereka kembali kepada ajaran Allah. Dan jika golongan itu telah kembali, maka damaikan keduanya dengan adil dan berlakulah adil. Sesungguhnya

${ }^{16}$ Profil dan Prosedur Badan Arbitase Syariah Nasional ( BASYARNAS), 3 Februari 2006, h.9 
Allah menyukai orang-orang yang berlaku adil"

Dalam surat an-Nisa ayat 35 juga ditegaskan bahwa:

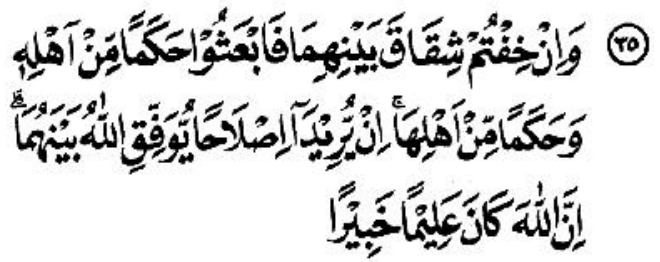

"Dan jika kamu khawatir terjadi sengketa diantara keduanya (suami istri), maka kirimkan seorang hakam dari keluarga laki-laki dan seorang hakam dari keluarga perempuan. Jika kedua hakam itu bermaksud mengadakan perbaikan (perdamaian), niscaya Allah akan memberi taufik kepada suami-istri itu. Sesungguhnya Allah Maha Mengetahui lagi Maka Mengenal."

Semangat dari tahapan ini adalah perdamaian. Pengakhiran dari kegiatan bermuamalah di mana masing-masing pihak mengoreksi, membuka diri, dan menerima kebaikan yang menjadi semangat utama dalam setiap perserikatan kerjasama dalam Islam. Kesalahan dan penolakan oleh salah satu pihak harus diselesaikan dengan melakukan musyawarah dan kembali pada semangat utama (niat baik) dari akad yang sudah disepakati.

\section{Penyelesaian Melalui Litigasi}

Penyelesaian melalui litigasi akan ditempuh oleh bank bilamana nasabah tidak ada niat baik atau tidak menunjukkan kemauan untuk memenuhi kewajibannya, padahal nasabah masih memiliki harta kekayaan yang tidak dikuasai oleh bank atau sengaja disembunyikan atau mempunyai sumber-sumber lain untuk menyelesaikan masalahnya. ${ }^{17}$

Sejak diundangkannya Undangundang Nomor 3 tahun 2006 tentang Peradilan Agama, "jika terjadi sengketa dalam bidang muamalah maka bisa diselesaikan melalui Pengadilan Agama." Dijelaskan bahwa tugas dan wewenang Peradilan Agama adalah memeriksa, memutus dan menyelesaikan perkara di tingkat pertama antara orang-orang beragama Islam di bidang perkawinan, waris, wasiat, hibah, waqaf, zakat, infaq, shadaqah dan ekonomi syariah. ${ }^{18}$

Perubahan pentingnya adalah bahwa Undang-undang Nomor 3 Tahun 2006 memperluas kekuasaan atau kewenangan pengadilan agama yang meliputi juga sengketa di bidang ekonomi syariah. Sebelum diberlakunya Undang-undang ini, sengketa ekonomi syariah tidak dapat diselesaikan di pengadilan agama, karena wewenang pengadilan agama dibatasi oleh Undang-Undang Nomor 7 Tahun 1989 yang hanya dapat memeriksa, memutus, dan menyelesaiakan perkara-perkara yang

${ }^{17}$ Lihat: Sutan Remy Sjahdeini, Kapita..., h.

${ }^{18}$ Pasal 49 Undang-Undang Nomor 3 Tahun 
Perbankan

menyangkut perkawinan, warisan, Syariah pada Pasal 55 juga wasiat, hibah, waqaf dan shadaqah. Artinya, di luar enam bidang tersebut, pengadilan agama tidak dapat memeriksa, memutus dan menyelesaikannya. Sehingga apabila ada sengketa ekonomi syariah yang membutuhkan penyelesaian melalui ligitasi, para pihak dapat menyelesaikannya di pengadilan negeri.

Kewenangan Pengadilan Agama sebagaimana disebutkan dalam Undang-undang Nomor 3 Tahun 2006 ini memberikan kejelasan dan kepastian bagi masyarakat maupun pelaku ekonomi syariah. Da mana ekonomi syariah yang dimaksud adalah perbuatan atau kegiatan usaha yang dilaksanakan menurut syariah, yang meliputi :
a. Bank Syariah
b. Asuransi Syariah
c. Reasuransi Syariah
d. Reksa Dana Syariah
e. Obligasi Syariah dan surat berharga berjangka menengah syariah
f. Sekuritas Syariah
g. Pembiayaan Syariah
h. Pegadaian Syariah
i. Dana Pensiun lembaga Keuangan Syariah

j. Bisnis Syariah dan

k. Lembaga Keuangan Mikro Syariah. menjelaskan bahwa:

a. Penyelesaian sengketa Perbankan Syariah dilakukan oleh pengadilan dalam lingkungan Peradilan Agama;

b. Dalam hal para pihak telah memperjanjikan penyelesaian sengketa selain sebagaimana dimaksud pada ayat (1), penyelesaian sengketa dilakukan sesuai dengan isi akad;

c. Penyelesaian sengketa sebagaimana dimaksud pada ayat (2) tidak boleh bertentangan dengan prinsip syariah.

Pasal ini memberi peluang bahwa penyelesaian yang mungkin timbul pada bisnis keuangan Syariah, dapat melalui ligitasi atau melalui pengadilan, dan pengadilannya adalah di Peradilan Agama. Namun demikian, penyelesaian sengketa juga bisa melalui musyawarah, mediasi perbankan, lembaga arbitrase, dan melalui pengadilan di lingkungan Peradilan Umum sepanjang disepakati oleh para pihak dalam akad.

Dengan demikian, sampai pada tahap ini, penyelesaian sengketa ekonomi Syariah dapat dilakukan sesuai dengan yang diperjanjikan dalam akad. Bentuknya ada dua yaitu non ligitasi dan ligitasi. Alternatifnya 
bisa melalui: 1) musyawarah; 2) mediasi perbankan; 3) Badan Arbitrase Syariah Nasional (Basyarnas); 4) pengadilan agama; dan 5) lembaga arbitrase lain/pengadilan dalam lingkungan Peradilan Umum sesuai kesepakatan dalam akad.

\section{E. KESIMPULAN}

Pembiayaan pada lembaga keuangan syariah harus dijaga kualitasnya berdasarkan prinsip kehatihatian. Prinsip kehati-hatian adalah pedoman pengelolaan lembaga keuangan Syariah yang wajib dianut guna mewujudkan lembaga yang sehat, kuat, dan efisien sesuai dengan ketentuan peraturan perundang-undangan. Penerapan prinsip ini diwujudkan saat melakukan analisa pembiayaan. Yaitu menganalisa keyakinan atas kemauan dan kemampuan calon nasabah untuk melunasi seluruh kewajiban pada waktunya. Keyakinan tersebut diperoleh dari penilaian dengan seksama terhadap watak, kemampuan, modal, agunan, dan prospek usaha dari calon nasabah penerima fasilitas (character, capacity, capital, collateral, condition).

Idealnya, pembiayaan berjalan dengan lancar, pihak lembaga sudah melakukan analisis dengan baik dan nasabah mematuhi apa yang telah disepakati dalam perjanjian. Namun, jika terjadi kesalahan dalam analisis oleh lembaga atau terjadi ketidakberdayaan pada nasabah, sehingga terjadi masalah. Maka baik pihak lembaga atau nasabah bisa melakukan upaya untuk menyelesaikannya, yaitu melakukan penyelamatan pembiayaan bermasalah dengan upaya restrukturisasi apabila nasabah masih mempunyai niat baik untuk menyelesaikannya, atau jika nasabah sudah tidak ada lagi niat baik dalam (tidak dapat diajak kerjasama) dalam upaya penyelamatan pembiayaan bermasalah, maka lembaga keuangan Syariah bisa menyelesaikannya dengan cara non ligitasi dan ligitasi.

\section{DAFTAR PUSTAKA}

at-Tariqi, Abdulah Abdul Husain., Ekonomi Islam Prinsip Dasar dan Tujua, Yogyakarta: Magistra Insania Press, 2004

Ibrahim, Azharsyah., Arinal Rahmati., “ Analsis Solutif Penyelesaian Pembiayaan Bermasalah di Bank Syariah: Kajian Pada Produk Murabahah di Bank Muamalat Indonesia Banda Aceh", Iqtishadia, Vol.10,No.1, 2017

Muhamad., Manajemen Pembiayaan Bank Syariah, Yogyakarta: UPP AMP YKPN, 2005.

Peraturan Bank Indonesia Nomor 13/9/PBI/2011 Tentang Perubahan atas Peraturan Bank Indonesia Nomor 10/PBI/2008 Tentang Restrukturisasi Pembiayaan Bagi Bank Syariah dan Unit Usaha Syariah

Profil dan Prosedur Badan Arbitase Syariah Nasional (BASYARNAS), 3 Februari 2006 
Sjadeini,Sutan Remy., Kapita Selecta Hukum Perbankan Jilid I, t.tp: t.th

Undang-Undang Nomor 21 Tahun 2008 Tentang Perbankan Syariah.

Undang-undang Nomor 3 tahun 2006 tentang Peradilan Agama.

Yahman., dkk., Bunga Rampai Hukum Aktual Dalam Perspektif Hukum Bisnis Kontraktual Berimplikasi Pidana dan Perdata, Surabaya: Mitra Mandiri, 2011.

Nur, Yasin., Hukum Ekonomi Islam Geliat Perbankan Syari'ah di Indonesia, Malang: UIN-Malang Press, 2009. 